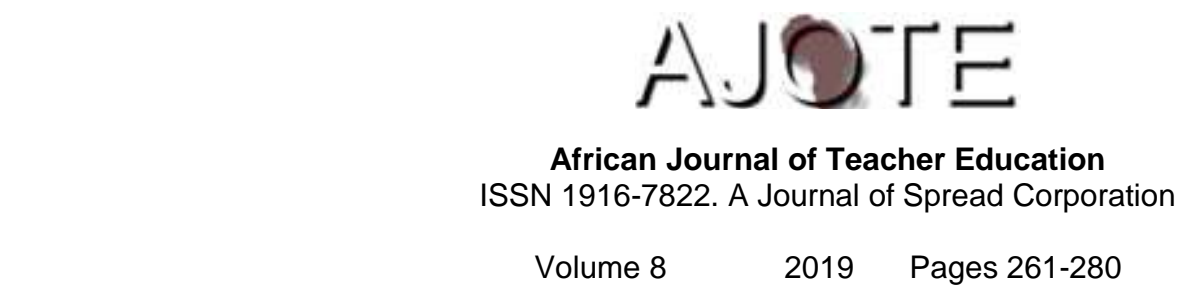

\title{
Underutilization of instructional materials for teaching and learning of Chemistry in Nigerian secondary schools: Ohafia Education Zone, Abia State's example.
}

\author{
Ngozi Obiyo \& James Inyama \\ Department of Educational Foundations, \\ University of Nigeria, Nsukka.
}

\begin{abstract}
This study investigated the factors associated with underutilization of instructional materials for teaching and learning of Chemistry in Nigeria. A survey research design was adopted for the study. The study population comprised 86 Chemistry teachers and 1,180 Senior Secondary 2 (SS2) Chemistry students including those with special needs in the 86 public secondary schools in Ohafia Education Zone, Abia State in southeast geopolitical zone of Nigeria. The sample size was 456 respondents of 57 Chemistry teachers and 399 SS 2 Chemistry students selected through multi-stage sampling procedure. The data collection was by questionnaire and Cronbach Alpha was applied in computing the reliability estimate of 0.97. The findings indicated that the inability of teachers to improvise and their lack of manipulative skills, among others, are factors militating against the utilization of instructional materials. The researchers recommended the necessity for adequate provision of instructional materials in the schools and for teachers to ensure that these materials are effectively utilized. Students with special needs should be catered for based on their individualized education program as stipulated by the National Policy on Education in inclusive settings.
\end{abstract}

Keywords: Chemistry, utilization, inclusive, instructional materials.

\section{Introduction}

Nigeria was one of the signatories to the Salamanca Declaration (1994), Dakar Framework for Action (2000), United Nations Convention on the Rights of Persons with Disabilities (2006) and Sustainable 
Development Goals (SDGs) developed by UN in 2015; all of which stipulated that the education of learners with special needs should be implemented through an Inclusive Education (IE) approach. The constitution of the Federal Republic of Nigeria strongly protects human rights, Nigeria's National Policy on Education (NPE) guarantees education for all without any discrimination, and the UBEC (Universal Basic Education Commission) Act-2004 emphasized free and compulsory education of all Nigerian children of school age irrespective of their diverse needs. Furthermore, the NPE stipulated the need for inclusion of children with special needs. It also touched on strategies for reducing dropout rates in primary education (Federal Ministry of Education, 2015). The core value of these treaties and policy documents are that all children have the right to receive education that does not discriminate on any grounds such as ethnicity, religion, economic status, language, gender, disability among others.

Students' achievement (including those with special needs) in Chemistry in public examinations in Nigeria has been poor over many years (Inyang and Ekpeyong, 2000; Igwe, 2006; WAEC Chief Examiners' Report for 1991-2008 and for May/June 2012; Jegede, 2010; Oloyede, 2010 and Omwirhiren, 2015). In 2010, out of the 185,430 candidates that sat for the Chemistry examination, $31.88 \%$ scored between A1-C6, while 68.12\% scored below C6 including F9. From 2011 to 2013, the percentage that scored C6 and above were 30.98\%, 30.69\%, and 30.00\% respectively while the percentage that scored below C6 were $69.02 \%, 69.39 \%$, and $70.00 \%$ respectively.

Table 1: Students, achievements in Chemistry for WASSCE

\begin{tabular}{|l|l|l|}
\hline Year & Percentage & Grade \\
\hline 2010 & 31.88 & A1-C6 \\
\hline & 68.12 & D7-F9 \\
\hline 2011 & 30.98 & A1-C6 \\
\hline & 69.02 & D7-F9 \\
\hline 2012 & 30.69 & A1-C6 \\
\hline & 69.39 & D7-F9 \\
\hline 2013 & 30.00 & A1-C6 \\
\hline & 70.00 & D7-F9 \\
\hline
\end{tabular}


Student enrolment in Chemistry between 2005 and 2009 was poor as depicted by the number of candidates that sat for the subject in the West African Senior School Certificate Examination (WASSCE):

Table 2: Students Chemistry enrolment for WASSCE

\begin{tabular}{|l|l|}
\hline Years & enrolment \\
\hline 2005 & 185,883 \\
\hline 2006 & 171,638 \\
\hline 2007 & 165,113 \\
\hline 2008 & 160,002 \\
\hline 2009 & 144,372 \\
\hline $2005-2009$ & 325,115 (Total Chemistry) \\
\hline
\end{tabular}

Further, in 2012, out of the 1.67 million candidates that sat for WASSCE, 122,000 candidates had their results withheld due to examination malpractice issues and this was a figure said to have been higher in previous years, especially in 2011 (Premium Times August 24, 2015). Samba, Achor, and Ogbeba (2010) had also lamented on the fall in the standard of science teaching in Nigeria. Nwagbo (2001) identified underutilization of instructional materials as chief among a number of factors militating against students' understanding and achievement in science subjects like Chemistry. Mathew and Onyejegbu, (2013) had observed that students taught with instructional materials perform better than those taught without instructional materials.

The Federal Republic of Nigeria (FRN, 2014) in its National Policy on Education stipulated that the quality of instruction should be oriented towards inculcating some values which included acquisition of functional skills and competencies necessary for self-reliance. Emphasis was placed on primary education but arbitrarily transplanting an elementary model of learning to the secondary level was not appropriate (Kokoszla \& Drye, 1981). The gap in performance between students with and without disabilities was more pronounced and academic expectations tend to increase at the secondary level (Packard, et al, 2011).

Chemistry had been made to look too abstract, difficult, and uninteresting. This could be eliminated or minimized by the use of appropriate instructional materials. Mboto and Ogar (2004), and Arokoyu (2005) reported conceptual difficulties with various chemical concepts by students which affected their understanding and performance in Chemistry. In an inclusive setting, this may be more 
difficult for persons with special needs in Nigeria. All students irrespective of disabilities were admitted in schools, but no special attention is given to persons with special needs. This may be minimized by the use of instructional materials for all students. Students (especially those with special needs) tend to find practical classes interesting because they are actively engaged. Passive learning through lectures may not provide a lasting interest in Chemistry for these students in an inclusive classroom. Instructional materials could help students, disability notwithstanding to connect to the object of study, and student participation may increase. This may help to increase their interest in the concept being studied (Nwoji, 2011).

Empirical studies in Nigeria and Israel respectively by Mboto and Ogar (2004), Hofstein (2004) and (2005), reported poor retention of students in Chemistry. This according to Laha (2008) has led students to engage in cheating or examination malpractices in public examinations which has attracted public concern and outcry in Nigeria.

Studies showed that where instructional materials were available in the area of study, they were not properly utilized or not used at all. Related but separate empirical studies by Emendu (2012), Nwosu (2010), Asubiojo and Aladejana (2013) Nwafor and Eze (2014) Tafi (2006), show that most of the schools in Ekiti state, Ebonyi state, all in Nigeria that they investigated had instructional materials. However, most of these materials were neither assembled nor utilized in teaching and learning activities in Chemistry. Teachers did not possess the necessary manipulative skills for the utilization of these materials. There were no special educators posted to the schools in the area of study. Other factors for underutilization of instructional materials included large class size, lack of facilities, time allocated to the teaching of each topic and methods of instruction (Asogwa, Onu and Egbo, 2013; Nwafor and Eze, 2014). Teachers' skill in the handling of instructional materials was also a major factor (Uzuegbu, Mbadiwe, and Anulobi, 2013). Nor were inclusive practices involved in teaching and learning to accommodate persons with special needs.

Available results from West African Examination Council in Ohafia Education zone of Abia State, Nigeria (area of study), showed' students' poor performance in Chemistry. Only a few students offered Chemistry including those with special needs. Data collected from statistical unit Secondary Education Management Board (SEMB), Ohafia zone, showed that out of the 96 students of Akanu Ohafia Secondary School, Ohafia, who sat for the WASSCE in the year 2011, only 26 sat for Chemistry while in 2012 WASSCE, out of 82 candidates, only 22 students sat for Chemistry in the same school. 
Statistical report on the number of students that sat for SS 2 centralized examination in the zone for Chemistry in 2015 showed that there was poor enrolment in many of the public schools.

The researchers' focused group discussion and field experience revealed that in some schools in this zone, there was a high incidence of examination malpractices. Some of the students complained of difficulty in understanding Chemistry concepts and mentioned it as one of the reasons for engaging in malpractices. The needs of special students were not taken care of in inclusive settings.

This study was guided by the following research questions and hypotheses tested at 0.05 level of significance to achieve the purpose of the study:

1. To what extent did Chemistry teachers utilize the available instructional materials for teaching and learning of Chemistry in the zone?

2. What were the factors militating against the utilization of instructional materials for teaching and learning of Chemistry in the zone?

3. In what ways could instructional materials be supplied for teaching and learning of Chemistry in the zone?

- HO1: There was no significant difference in the mean ratings of teachers and students on the utilization of the available instructional materials for teaching and learning of Chemistry in the zone.

- HO2: There was no significant difference in the mean ratings of teachers and students on the factors militating against the utilization of instructional materials for teaching and learning of Chemistry in the zone.

This study adopted a survey research design. It was adopted because a group of people and items were studied by collecting and analyzing data considered representative of the entire group in this research (Nworgu, 2006).

The study covered all the Public Secondary Schools in Ohafia Education Zone of Abia State, Nigeria. Abia state was made up of three education zones namely: Aba, Ohafia, and Umuahia with a uniform educational administrative structure in all the zones. Ohafia Education Zone comprised the following Local Government Areas (LGA) which also served as education sub-zones, namely: Arochukwu, Bende, Isuikwuato, and Ohafia. Ohafia Education Zone was chosen for the study because 
there was evidence that students performed poorly in Chemistry in public examinations in this zone. This also applied to those with special needs.

The population of the study consisted of all 86 Chemistry teachers in 86 public secondary schools and all 1,180 SS2 (Senior Secondary 2) Chemistry students in the zone. The zone consists of 18, 26, 15 and 27 public secondary schools for Arochukwu, Bende, Isuikwuato and Ohafia subzones/L.G.A., respectively (Statistics Unit, Secondary Education Management Board (SEMB), Ohafia Education Zone, Abia State, 2016). The teachers were all qualified and each possessed a minimum certificate of National Certificate in Education (NCE). They were males and females. Regrettably, there were no special educators attached to any of the schools. There was no inclusion.

A sample of 456 respondents comprising of 57 Chemistry teachers (all qualified and trained as per state regulations) and 399 SS2 Chemistry students in the public secondary schools in the zone was used for the study. The multi-stage sampling procedure was used to draw the sample for the study. The schools in this zone were already stratified into four sub-zones: Arochukwu, Bende, Isuikwuato, and Ohafia.

In the first stage, purposive and proportionate stratified sampling techniques were used to select 57 schools from different sub-zones; 12 out of 18 from Arochukwu, 17 out of 26 from Bende, 10 out of 15 from Isuikwuato and 18 out of 27 from Ohafia sub-zones. There was no special school for students with special needs in the zone and inclusion was not practiced.

The sample size comprised of 84, 119, 70 and 126 SS2 Chemistry students for each of the subzone of Arochukwu, Bende, Isuikwuato and Ohafia respectively, making a total of 399 Chemistry students. Thus a total of 456 respondents (teachers and students) were involved in the study, which is about $36.0 \%$ of the total population $(1,266)$ (teachers and students).

This study was anchored on Jean Piaget's (1964) theory of intellectual development. The theory stated that cognitive development took place from the active interaction of a child with his environment. The theory helped both the teacher and learner to understand that utilization of instructional materials offered the learner the opportunity to interact with his environment. This made the learners, including those with special needs, to be actively involved in the learning process. [It states that methods of meeting goals and objectives should be discussed openly. Other teaching professionals were needed to be directly or indirectly involved with the students, disability notwithstanding. 
The instrument for data collection was the Utilization of Different Instructional Materials Questionnaire (UDIMQ). It had two sections, A and B. Section A' sought personal information of the respondents. Section B was divided into three clusters A, B and C. Cluster A contained 25 items on the utilization of the available instructional materials by Chemistry teachers. Cluster B comprised 13 item statements on the factors militating against the utilization of instructional materials for teaching and learning of Chemistry. Cluster $\mathrm{C}$ comprised 10 item statements on ways that the instructional materials were supplied for teaching and learning of Chemistry in the zone.

A four-point rating scale was used for Clusters A, B and C. For cluster A, it was, Very Great Extent $(\mathrm{VGE}=4)$, Great Extent $(\mathrm{GE}=3)$, Low Extent $(\mathrm{LE}=2)$, Very Low Extent (VLE $=1)$. For clusters B and C they were, Strongly Agree $(S A=4)$, Agree $(A=3)$, Disagree $(D=2)$, Strongly Disagree $(\mathrm{SD}=1)$.

The instrument was validated by three experts to ensure face validity. Two experts were from Science Education and one expert from Measurement and Evaluation from the University of Nigeria, Nsukka. Their corrections and suggestions were used in the final production of the present instrument.

To determine the reliability of the instrument (in this case, an estimate of internal consistency), trial testing was carried out using schools that were outside the zone. 10 Chemistry teachers and 10 Chemistry students were randomly selected at Aba Education Zone of Abia State. Using Cronbach Alpha method, the reliability coefficients were estimated. The following reliability coefficients were obtained $0.65,0.88$ and 0.78 . The overall reliability of the instrument was 0.97 . Teachers (males and females and all qualified by state standards) recorded cluster mean score of 1.89 and students (both males and females) recorded 1.94. Comparatively, students had higher cluster mean score than teachers but there was agreement on underutilization of instructional materials. The standard deviation of the respondents ranged from $0.09-0.96$. This was very close to the overall reliability of 0.97 . These results showed that the instrument was reliable.

Face to face administration of the instrument was adopted. This ensured a $100 \%$ rate of return of the instrument. It also helped the researchers/assistants to explain items the respondents did not understand very well. They were administered to the respondents and retrieved on the spot after completion. Two research assistants helped the researchers in the distribution and retrieval of the instrument. 
The hypotheses were tested using t-test and tested at an alpha level of significance of 0.05 . The research questions were answered by a mean and standard deviation. For cluster A, the real limit of the number was used to interpret it as follows: 1.00-1.49, very low extent (VLE), 1.50-2.49, low extent, 2.50-3.49, great extent (GE), 3.50-4.00, very great extent (VGE). Mean value of 2.50 and above was the benchmark for acceptance for clusters B and C while any value below 2.50 was rejected.

\section{Results}

The data for answering research question \#1 was presented in table 3.

Table 3: Mean ratings of teachers and students on the extent of utilization of available instructional materials by Chemistry teachers in the area.

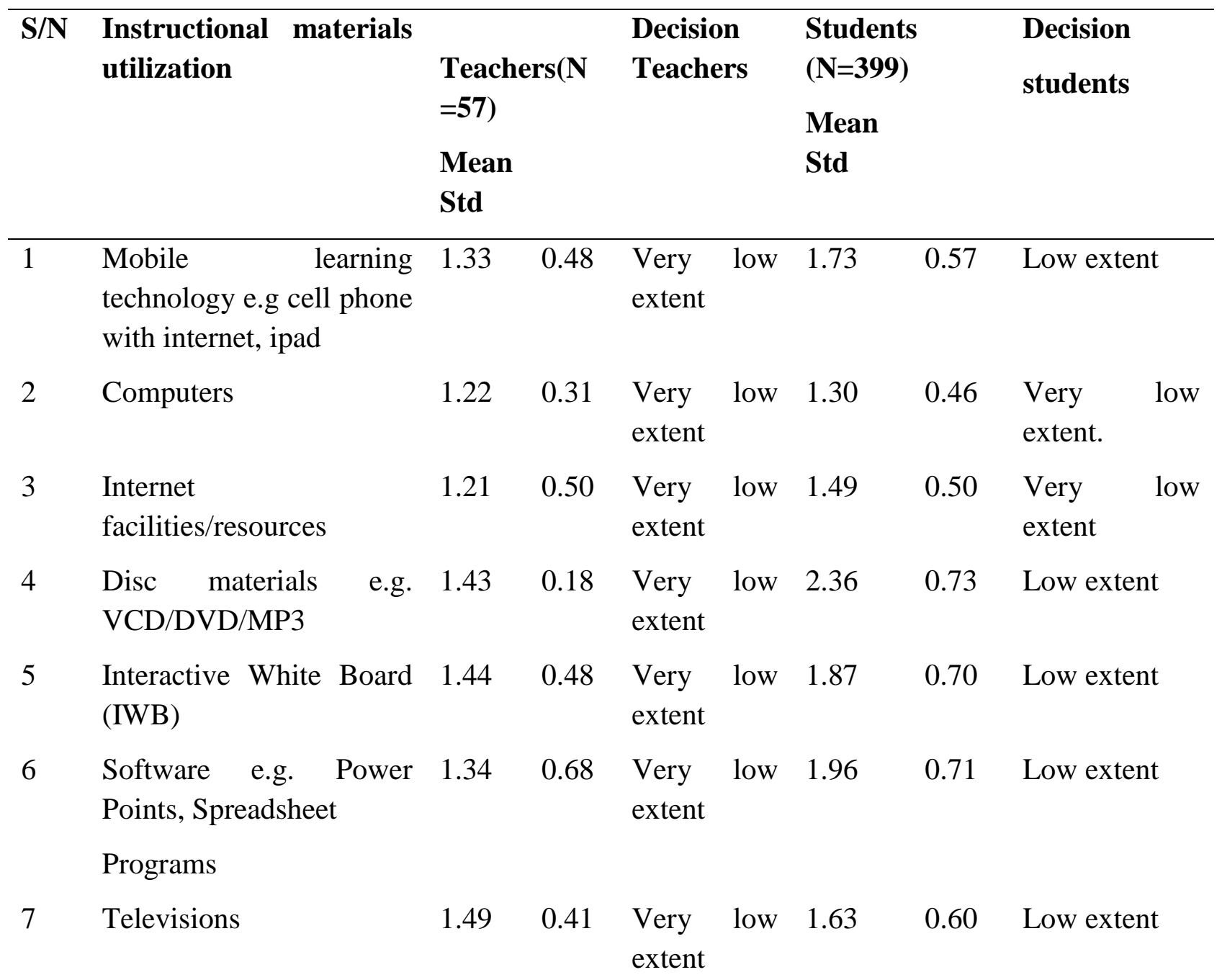


Underutilization of instructional materials for teaching and learning of Chemistry in Nigerian secondary schools: Ohafia Education Zone, Abia State's example.

\begin{tabular}{|c|c|c|c|c|c|c|c|}
\hline 8 & Projectors & 1.34 & 0.50 & $\begin{array}{l}\text { Very low } \\
\text { extent }\end{array}$ & 2.37 & 0.73 & Low extent \\
\hline 9 & Still and motion pictures & 1.28 & 0.73 & $\begin{array}{l}\text { Very low } \\
\text { extent }\end{array}$ & 2.22 & 0.62 & Low extent \\
\hline 10 & $\begin{array}{l}\text { Models e.g molecular } \\
\text { models }\end{array}$ & 2.35 & 0.96 & Low extent & 1.44 & 0.50 & $\begin{array}{l}\text { Very low } \\
\text { extent }\end{array}$ \\
\hline 11 & Mobiles & 1.28 & 0.33 & $\begin{array}{l}\text { Very low } \\
\text { extent }\end{array}$ & 2.01 & 0.71 & Low extent \\
\hline 12 & $\begin{array}{l}\text { Pictures e.g. photographs, } \\
\text { drawings }\end{array}$ & 1.35 & 0.79 & $\begin{array}{l}\text { Very low } \\
\text { extent }\end{array}$ & 2.32 & 0.50 & Low extent \\
\hline 13 & Workbooks & 1.21 & 0.64 & $\begin{array}{l}\text { Very low } \\
\text { extent }\end{array}$ & 2.15 & 0.69 & Low extent \\
\hline 14 & $\begin{array}{l}\text { Journals, periodicals, } \\
\text { magazines }\end{array}$ & 1.42 & 0.69 & $\begin{array}{l}\text { Very low } \\
\text { extent }\end{array}$ & 1.81 & 0.77 & Low extent \\
\hline 15 & $\begin{array}{l}\text { Graphic materials e.g. } \\
\text { charts }\end{array}$ & 1.96 & 0.68 & Low extent & 2.41 & 0.50 & Low extent \\
\hline 16 & Realia (real objects) & 1.54 & 0.83 & Low extent & 2.22 & 0.67 & Low extent \\
\hline 17 & $\begin{array}{l}\text { Local materials (fruits, } \\
\text { ashes, shells, palm oil) }\end{array}$ & 1.67 & 0.48 & Low extent & 2.41 & 0.98 & Low extent \\
\hline 18 & Burettes & 1.75 & 0.79 & Low extent & 1.32 & 0.47 & $\begin{array}{l}\text { Very } \\
\text { extent }\end{array}$ \\
\hline 19 & Test tubes & 2.46 & 0.80 & Low extent & 2.10 & 0.55 & Low extent \\
\hline 20 & Burnsen burners & 1.33 & 0.48 & $\begin{array}{l}\text { Very low } \\
\text { extent }\end{array}$ & 1.84 & 0.93 & Low extent \\
\hline 21 & $\begin{array}{l}\text { Conc Acids e.g. } \mathrm{HCl} \text {, } \\
\mathrm{H}_{2} \mathrm{SO}_{4}, \mathrm{HNO}_{3}\end{array}$ & 2.11 & 0.73 & Low extent & 2.02 & 0.44 & Low extent \\
\hline 22 & Alkalis e.g. $\mathrm{NaOH}, \mathrm{KOH}$, & 2.28 & 0.82 & Low extent & 0.95 & 0.95 & Low extent \\
\hline 23 & Chemical balance & 2.13 & 0.72 & Low extent & 1.88 & 0.53 & Low extent \\
\hline 24 & $\begin{array}{l}\text { Distillation apparatus e.g. } \\
\text { condensers }\end{array}$ & 1.33 & 0.47 & $\begin{array}{l}\text { Very low } \\
\text { extent }\end{array}$ & 1.38 & 0.64 & $\begin{array}{l}\text { Very low } \\
\text { extent }\end{array}$ \\
\hline 25 & $\begin{array}{l}\text { Apparatus for electrolysis } \\
\text { e.g. voltammeters }\end{array}$ & 1.39 & 0.48 & $\begin{array}{l}\text { Very low } \\
\text { extent }\end{array}$ & 1.90 & 0.61 & Low extent \\
\hline & Cluster mean & 1.89 & 0.09 & Low extent & 1.94 & 0.12 & Low extent \\
\hline
\end{tabular}


Data presented in table 3 revealed the mean ratings of teachers and students on the extent of utilization of the available instructional materials for teaching and learning of Chemistry in the area. Their mean score ranged from 1.28 to 1.49 for teachers and 1.63 to 2.37 to 2.37 for students.

Teachers recorded cluster mean score of 1.89 while students recorded cluster mean score of 1.94. The table showed that the standard deviation of the respondents ranged from 0.09 to 0.96 indicating that the respondents were not too far from the mean and from the opinion of one another in their responses. To further answer this research question, the following hypothesis was raised:

- There was no significant difference between the mean ratings of teachers and students on the extent of utilization of available instructional materials for the teaching and learning of Chemistry.

Table 4: T-test statistics of the mean ratings of teachers and students on the extent of utilization of available instructional materials for teaching and learning of Chemistry.

\begin{tabular}{llllllll}
\hline & $\mathbf{N}$ & Mean & Std & df & t & $\begin{array}{l}\text { Sig } \\
\text { tailed })\end{array}$ & \\
\hline Teachers & 57 & 1.89 & 0.09 & 454 & -3.12 & 0.00 & Significant \\
Students & 399 & 1.94 & 0.12 & & & & \\
\hline
\end{tabular}

Data presented in Table 4 indicated that the probability value (0.00) is less than the level of significance (0.05) at 454 degrees of freedom (DF). The null hypothesis was therefore rejected. This implied that there was a significant difference between the mean ratings of teachers and students on the extent of utilization of available instructional materials for the teaching and learning of Chemistry in the area $(\mathrm{P}<0.05)$. 
Table 5: Mean ratings of teachers and students on factors militating against the utilization of instructional materials for teaching and learning of chemistry in the zone.

\begin{tabular}{|c|c|c|c|c|c|c|c|}
\hline \multirow[t]{3}{*}{$\begin{array}{l}\mathbf{S} / \\
\mathbf{N}\end{array}$} & \multirow[t]{3}{*}{ Item statement } & \multirow{2}{*}{\multicolumn{2}{|c|}{$\begin{array}{l}\text { Teachers }(N=5 \\
\text { 7) }\end{array}$}} & \multirow{3}{*}{$\begin{array}{l}\text { Decision } \\
\text { Teacher } \\
\text { S }\end{array}$} & \multicolumn{2}{|c|}{$\begin{array}{l}\text { Students }(\mathrm{N}=3 \\
\text { 99) }\end{array}$} & \multirow{3}{*}{$\begin{array}{l}\text { Decision } \\
\text { students }\end{array}$} \\
\hline & & & & & \multirow{2}{*}{ Mean } & \multirow{2}{*}{ Std } & \\
\hline & & Mean & Std & & & & \\
\hline 1 & $\begin{array}{l}\text { Lack of commitment by } \\
\text { chemistry teachers }\end{array}$ & 2.68 & 0.63 & Agree & 3.04 & 0.72 & Agree \\
\hline 2 & $\begin{array}{l}\text { Lack of manipulative skills/ } \\
\text { technicians or operators }\end{array}$ & 3.09 & 0.58 & Agree & 3.02 & 0.55 & Agree \\
\hline 3 & $\begin{array}{l}\text { Lack of facilities (e.g. } \\
\text { electricity) }\end{array}$ & 2.79 & 0.56 & Agree & 2.65 & 0.55 & Agree \\
\hline 4 & Resistance to innovations & 2.93 & 0.68 & Agree & 2.87 & 0.66 & Agree \\
\hline 5 & Large class size & 2.32 & 0.83 & Disagree & 2.39 & 0.84 & Disagree \\
\hline 6 & $\begin{array}{l}\text { Poor teacher training at } \\
\text { colleges/universities offering } \\
\text { education courses }\end{array}$ & 2.98 & 0.52 & Agree & 2.95 & 0.54 & Agree \\
\hline 7 & $\begin{array}{l}\text { Methods of instruction used in } \\
\text { my school do not require it }\end{array}$ & 2.45 & 0.79 & Disagree & 2.43 & 0.77 & Disagree \\
\hline 8 & $\begin{array}{l}\text { Instructional material is time } \\
\text { consuming }\end{array}$ & 2.92 & 0.96 & Agree & 2.92 & 0.98 & Agree \\
\hline 9 & $\begin{array}{l}\text { Non-availability of the required } \\
\text { materials }\end{array}$ & 2.60 & 0.73 & Agree & 2.66 & 0.74 & Agree \\
\hline 10 & $\begin{array}{l}\text { Time allocated to the teaching of } \\
\text { each topics is short }\end{array}$ & 2.81 & 0.40 & Agree & 2.80 & 0.40 & Agree \\
\hline 11 & $\begin{array}{l}\text { Poor internal supervision by } \\
\text { school authorities }\end{array}$ & 3.21 & 0.84 & Agree & 3.51 & 0.81 & Agree \\
\hline 12 & $\begin{array}{l}\text { Lack of motivation, } \\
\text { encouragement and support } \\
\text { from school authorities }\end{array}$ & 2.72 & 0.63 & Agree & 2.76 & 0.64 & Agree \\
\hline \multirow[t]{2}{*}{13} & $\begin{array}{l}\text { Inabilities of teachers to build } \\
\text { lessons on power point }\end{array}$ & 2.67 & 0.89 & Agree & 2.59 & 0.85 & Agree \\
\hline & Cluster mean & 2.68 & 0.08 & Agree & 2.75 & 0.25 & Agree \\
\hline
\end{tabular}


Data presented in table 5 was used to answer research question \#2. It revealed the mean ratings of teachers and students on factors militating against the utilization of instructional materials for teaching and learning of Chemistry in the zone. All the items except items 5 and 7 were rated above the benchmark value of 2.50. Their mean scores ranged from 2.60 to 3.51 .

Teachers recorded cluster mean score of 2.68 while students recorded cluster mean score of 2.75. The table showed that the standard deviation of respondents ranged from 0.08 to 0.98 , indicating that the respondents were not too far from the mean and from the opinion of one another in their responses. To further answer this research question, the following hypothesis was raised:

- There was no significant difference between the mean ratings of teachers and students on the factors militating against the utilization of instructional materials for the teaching and learning of Chemistry in the zone

Table 6: t-test statistics of the mean ratings of teachers and students on the factors militating against the utilization of instructional materials for teaching and learning of Chemistry in the area

\begin{tabular}{lllllllll}
\hline Teachers & $\mathbf{N}$ & Mean & Std & df & $\mathbf{t}$ & $\begin{array}{l}\text { Sig } \\
\text { tailed }\end{array}$ & & \\
& & & & & & Decision \\
Teacher & 57 & 2.68 & 0.08 & 454 & -2.13 & 0.03 & Significant \\
students & 399 & 2.25 & 0.25 & & & & \\
\hline
\end{tabular}

Data presented in Table 6 indicated that the probability value (0.03) is less than the level of significance (0.05) at 454 degrees of freedom (DF). The null hypothesis was therefore rejected. This implied that there was a significant difference between the mean ratings of teachers and students on the factors militating against the utilization of instructional materials for the teaching and learning of Chemistry in the zone $(\mathrm{P}>0.05)$. 
Table 7: Mean and standard deviation of the responses of teachers and students on ways in which instructional materials are supplied for teaching and learning of Chemistry in the zone.

\begin{tabular}{|c|c|c|c|c|c|c|c|}
\hline \multirow[t]{2}{*}{$\mathbf{S} / \mathbf{N}$} & \multirow[t]{2}{*}{ Item statement } & \multicolumn{2}{|c|}{ Teachers(N=57) } & \multirow[t]{2}{*}{$\begin{array}{l}\text { Decision } \\
\text { Teachers }\end{array}$} & \multicolumn{2}{|c|}{$\begin{array}{l}\text { Students } \\
(\mathrm{N}=399)\end{array}$} & \multirow[t]{2}{*}{$\begin{array}{l}\text { Decision } \\
\text { students }\end{array}$} \\
\hline & & Mean & Std & & $\begin{array}{l}\text { Mea } \\
\text { Std }\end{array}$ & & \\
\hline 1 & Improvisation by teachers & 2.62 & 0.60 & Agree & $\begin{array}{l}3.1 \\
0\end{array}$ & 0.55 & Agree \\
\hline 2 & $\begin{array}{l}\text { Supply by principals } \\
\text { through school income }\end{array}$ & 2.72 & 0.30 & Agree & $\begin{array}{l}3.2 \\
0\end{array}$ & 0.74 & Agree \\
\hline 3 & $\begin{array}{l}\text { Supply by Ministry of } \\
\text { Education (State and } \\
\text { Federal) }\end{array}$ & 2.51 & 0.66 & Agree & $\begin{array}{l}2.5 \\
8\end{array}$ & 1.08 & Agree \\
\hline 4 & $\begin{array}{lr}\text { Supply by } & \text { School } \\
\text { Management } & \text { Board } \\
(\text { SEMB) } & \end{array}$ & 2.61 & 0.13 & Agree & $\begin{array}{l}2.9 \\
9\end{array}$ & 0.70 & Agree \\
\hline 5 & $\begin{array}{ll}\text { Donations } & \text { from } \\
\text { philanthropists } & \end{array}$ & 2.79 & 0.77 & Agree & $\begin{array}{l}2.8 \\
5\end{array}$ & 0.91 & Agree \\
\hline 6 & $\begin{array}{l}\text { Distribution of production } \\
\text { by students in tertiary } \\
\text { institutions }\end{array}$ & 2.59 & 0.52 & Agree & $\begin{array}{l}2.8 \\
0\end{array}$ & 0.77 & Agree \\
\hline 7 & Donations from PTA & 2.71 & 0.73 & Agree & $\begin{array}{l}2.9 \\
6\end{array}$ & 0.58 & Agree \\
\hline 8 & Production by the students & 2.65 & 0.52 & Agree & $\begin{array}{l}3.2 \\
0\end{array}$ & 0.76 & Agree \\
\hline 9 & $\begin{array}{l}\text { Supply by UNICEF/World } \\
\text { Bank }\end{array}$ & 2.90 & 0.57 & Agree & $\begin{array}{l}2.5 \\
4\end{array}$ & 0.82 & Agree \\
\hline 10 & $\begin{array}{l}\text { Supply by community, } \\
\text { clubs, and other } \\
\text { organizations }\end{array}$ & 2.54 & 0.64 & Agree & $\begin{array}{l}3.0 \\
8\end{array}$ & 0.80 & Agree \\
\hline & Cluster mean & 2.58 & 0.58 & Agree & $\begin{array}{l}2.9 \\
0\end{array}$ & 0.33 & Agree \\
\hline
\end{tabular}


Data presented in table 7 answered research question \#3. It revealed the mean responses and standard deviation of teachers and students on the ways in which instructional materials could be supplied for teaching and learning of Chemistry in the area. All the items were rated above the benchmark value of 2.50. Their mean scores ranged from 2.51 to 3.20. Teachers recorded cluster mean score of 2.58 while students had a cluster mean score of 2.90 .

\section{Discussion}

The findings from research question \#1 showed that teachers utilized the available instructional materials to a very low extent which included computers, molecular models, pictures, burettes, test tubes, acids, alkalis and chemical balance among others. The high technology ones such as internet facilities, mobile learning technology, and software among others were not available, therefore were not even utilized. These were in agreement with the findings of Nwosu (2010) that computers and other Information Communication Technology (ICT) tools were utilized to a very low extent by teachers. It was also in agreement with the findings of Asubiojo and Aladejana (2013) that available instructional materials were not adequately utilized.

However, the results were contrary to the findings of Emendu (2012) who noted that $60 \%$ of Chemistry teachers agreed that the listed materials in that study were utilized while $40 \%$ of teachers agreed that they were not utilized. This disparity may be due to the type of materials involved. The study by Emendu focused mainly on simple laboratory equipment while the present study include both simple and equally high technology ones. The findings showed that there was a significant difference between the mean ratings of teachers and students on the extent of utilization of these materials.

The findings from research question \#2 showed that lack of manipulative skills, a method of instruction used, time allocated to the teaching of each topic' and inability of teachers to build lessons on PowerPoint among others were factors militating against the utilization of instructional materials. These were in agreement with the findings of Asogwa, Onu and Egbo (2013), Uzuegbu, Mbadiwe and Anulobi (2013). The findings also showed that there was a significant difference between the mean ratings of teachers and students on factors militating against the utilization of instructional materials.

The findings from research question \#3 revealed ten ways the respondents agreed that instructional materials could be supplied to schools in the zone. They included improvisation by teachers, supply by school authorities, donations from Parents Teachers Association (PTA), 
philanthropists, community and other organizations among others. These were in agreement with the findings of Arokoyu (2005).

The study findings show that many best practices were not followed in the schools in the area of study. Schools did not arrange resources and administrative management processes to be inclusive. Parents of non-disabled students were not provided with general information on the purpose of inclusion. There was no consistent communication with paraprofessionals. The methodology [what methodology??] should be developed as a tool to keep students by increasing their learning motivation. Links should be developed between practical activities and teaching content (Vannest, et al, 2011).

\section{Conclusions}

The study identified some factors militating against the utilization of instructional materials in Ohafia. There was a significant difference between the teachers' and students' mean response, hence, for this, the null hypothesis was rejected. The study determined ten ways that instructional materials could be supplied for teaching and learning of Chemistry in the zone. There was no individualized education program for students with special needs in inclusive settings. This would greatly hurt inclusive education because students with special needs may be neglected. This study observes that there were no concrete plans to accommodate special needs students. This may hinder some of them from attaining their maximum capabilities as they may not get the necessary practical experience requirements. Also, the research shows that most students were more interested in getting the certificate to go to the university.

\section{Implications for inclusive education}

All categories of students with special needs are found in Nigerian regular education classes. Students with special needs that were offering Chemistry were part of this study, though, they were not singled out to avoid any form of extraneous bias. The important thing was that they were all involved with the poor enrolment of Chemistry and they were performing poorly. They were also involved in examination malpractices as identified from focus group discussions.

Based on these, the implication was that they should also be taught with instructional materials to be able to benefit from them. Within the classrooms and laboratories, regular educator (Chemistry teacher), laboratory scientist, signer, and special education teachers should provide instruction, through team teaching, co-teaching, parallel teaching, small group, and large group instruction. 
Moreover, due to their physical challenges, students with special needs require individualized educational program (IEP), that could cater for each student's special interest. Weekly joint planning time between regular and special educators would allow for the development of collaborative lesson plans. Collaborative skills that are necessary for inclusion were important to the success of the program what program? As team members of the IEP, parents, and families should be made aware of the continuum of activities available to students. They should assist in constructing schedules in order to meet students in the least restrictive environment.

The students and teachers should undergo intensive training to ensure proper utilization of instructional materials. The school, PTA, and other bodies should collaborate to make the instructional materials available to students. Parent conferences should be held jointly with regular Chemistry teachers and special educators. Parents of non-disabled students should be provided with general information about inclusion. They should be informed that other teaching professionals will, directly and indirectly, be involved with their own children. Change of attitude and internal motivation from the school community will make for meaningful inclusion of diverse children in various fields of school life. There should be consistent communication with special educators, regular class teachers and paraprofessionals such as audiologists, signers and speech therapists. The professional standard of the teaching team could be heightened as a result of working together, thereby raising the quality of instruction for students.

The government should be actively involved in the education of persons with special needs to follow up policies with implementation. Regular class teachers' special interests must also be taken care of in inclusive classrooms. Efforts should be made to include all stakeholders in the education of special needs students in the provision of resources. Regular class teachers could be encouraged to take online courses on inclusive education. Workshops may be organized for teachers and entrepreneurs and other stakeholders for possible synergy. The teachers and school authorities should remember that no child should be left behind. Special accommodations must be made for them to learn and understand chemical concepts. Instructional materials should be adapted for each student's special use and need. There was a need to attach practical values to what they learn in class.

Collaborative efforts involving philanthropists, the community and the school are needed to make instructional materials available and to ensure that they are appropriately utilized. Provisions 
should be made in the school budget for purchase of relevant instructional materials, teachers should improvise and encourage students to do the same.

\section{Recommendations}

1. Government and all other stakeholders in education should ensure adequate provision of instructional materials in the schools.

2. Resource centers should be established in each of the education zones in the state.

3. Teachers should ensure effective utilization of the instructional materials provided and not just to allow them to rot in a store. Teachers and students will need orientation in form of workshop on how to use the augmentative and assistive instructional materials that all students need, disability notwithstanding.

4. There is an urgent need for the government through the relevant agencies to organize workshops and seminars for teachers and other school authorities on the utilization of instructional materials.

5. Teachers should make a conscious effort on their own to update their knowledge on the use of Information Communication Technology (ICT), power points and other application software.

6. The teacher training institutions should ensure that student teachers are given proper training in the area of educational technology in order to expose them to modern instructional technology and how to manipulate them.

\section{References}

Akanu Ohafia Secondary School (2012). West African Senior School Certificate Examination (WASSCE) result sheet. Statistics unit, Secondary Education Management Board (SEMB), Ohafia Zone, Abia State.

Arokoyu, A. A. (2005). Investigation of SS 3 students' understanding of the atomic and mole concepts in Rivers State. Journal of Vocational and Technical Education, 2 (2), 146-151.

Asogwa, V. C., Onu, D. O. \& Egbo, B. N. (2013). Availability and utilization of instructional materials for effective teaching of fish production to students in senior secondary schools in Benue State, Nigeria. African Journal of Agricultural Research, 8(49), 6601-6607. Retrieved online from www.academijournals.org/AKAR on 20/11/2014. 
Asubiojo, R. O. \& Aladejana, A. O. (2013). Utilization of instructional materials by physics teachers and students in Ekiti State secondary schools, Nigeria. Journal of Research in Education and Society, 4(3), 93-100. Retrieved online from www.google on 25/08/2015.

Emendu, N. B. (2012). Effect of availability and utilization of chemistry laboratory equipment on SS 2 student's achievement in chemistry. Retrieved online from www.google.com on 27/08/2015.

Federal Republic of Nigeria (2014). National policy on education (6th edition). Lagos: NERDC Press.

Federal Ministry of Education (2015). National policy on special needs education in Nigeria. Abuja: NERDC Press.

Hofstein, A. (2004). The laboratory in chemistry education: Thirty years of experience in developments; implementation and research. Chemistry Education Research Practice, 5(3), 229245.

Hoftstein, A. (2005). The measurement of the education effectiveness of laboratory work in high school $\begin{array}{lllll}\text { chemistry in } & \text { Israel. } & \text { Retrieved }\end{array}$ http.Stwww.weizmann.acil/menu/dissertations/aviHofteinhtm on 18/10/2012.

Igwe, I. O. (2006). Relative effectiveness of concept mapping and framing instructional strategies on students' achievement in selected chemistry topics. Ebonyi State University Journal of Education, 4(1), 53-62.

Inyang, N. E. U. \& Ekpenyong, A. (2000). Influence of ability and gender groupings on senior secondary school chemistry students' achievement on the concept of redox reactions. Journal of Science Teachers Association of Nigeria, 35 (1 \& 2), 36-42.

Jegede, S. A. (2010). Nigerian students' perception of technical words in senior secondary school chemistry curriculum. Pakistan Journal of Social Sciences, 7(2), 109-111.

Kokosczka, R. \& Drye, J. (1981). Towards the least restrictive environment: High school learning disabled students. Journal of Learning Disabilities. 14 (1), 22-33.

Laha, B. B. (2008). New perspectives in examination malpractices in Nigeria. Makurdi: Selfers Academic Press.

Matthew, C. N. \& Onyejegbu, C. (2013). Effects of use of instructional materials on students' cognitive achievement in Agricultural Science. Journal of Educational and Social Research, 3(5), 103-107. 
Mboto, F. A. \& Ogar, N. E. (2004). The relative effectiveness of guided and expository laboratory on students' retention of physics concepts. International Journal of Research in Educational Development Consortia, 1(1), 151-163.

McLesky, J., Landers, E., Williamson P. \& Hoppey, D. (2012). Are we moving toward educating students with disabilities in least restrictive settings? Journal of Special Education, 46 (3), 131-140

Nwafor, C. E. \& Eze, S. O. (2014). Availability and utilization of instructional materials in teaching Basic Science in selected secondary schools in Abakaliki Education Zone of Ebonyi State, Nigeria. Global Journal of Bio-Science and Biotechnology, 3(3), 292-295.

Nwagbo, C. (2001). The relative efficacy of guided inquiry and expository methods on the achievement in biology students of different levels of scientific literacy. Journal of Science Teachers Association of Nigeria, 36 (182), 43-51.

Nwoji, Q. J. (2011). Production and utilization of teaching materials (Revised edition). Enugu: Fulladu.

Nworgu, B. G. (2006). Educational research: Basic issues and methodology (Second and enlarged edition). Nsukka, Enugu: University Trust.

Nwosu, E. N. (2010). Utilization of Information Communication Technology (ICT) as a tool and strategies for improving teacher professional development for effective service delivery. International Journal of Educational Research, 11 (2): 134-143.

Oloyede, O. I. (2010). Effect of enhanced mastery learning strategy on the achievement and self concept of students in senior secondary school Chemistry. Humanity and Social Sciences Journal 5(1), 19-24.

Omwirhiren, E. M. (2015). Enhancing academic achievement and retention in senior secondary school chemistry through discussion and lecture methods: A case study of some selected secondary schools in Gboko, Benue State, Nigeria. Journal of Education and Practice, 6 (21), 155-161.

Packard, A. L., Hazelkorn, M., Harris, K. P. \& McLeod, R. (2011). Academic achievement of secondary students with learning disabilities in co taught and resource. Journal of Research in Education. 21 (2), 100-117.

Piaget, J. (1964). The origins of intelligence in children. New York: Norton. 
Samba, R. M. O., Achor, E. E. \& Ogbeba, J. A. (2010). Teachers' awareness and utilization of innovative teaching strategies in secondary school science in Benue State, Nigeria. Journal of Educational Research, 192, 32-28. Retrieved online from http://www.interesjournal.org on 20/10/2010.

Uzuegbu, C. P., Mbadiwe, H. C. \& Anulobi, J. C. (2013). Availability and utilization of instructional materials in teaching and learning of library education in tertiary institutions in Abia State. Wudpecker Journal of Educational Research, 2(8), 111-120.

Vannest, K. J.,Burke, S. H., Parker, R. I. \& Soares, D. A. (2011). Special education teacher time use in four types of programs. Journal of Educational Research. 104 (4), 219-230.

WAEC Releases 2012 result, withholds 122 thousand certificates (2012, August 10). Premium times. Retrieved online from www.google.com on August 24, 2015.

West African Examination Council (WAEC, 2012). Chief examiner's report. Lagos: WAEC. 